\title{
SIGNAGE DAN PENERAPANNYA: LINGKUNGAN JALAN RAYA TOL BINTARO
}

\author{
Dyah Gayatri Puspitasari; James Darmawan \\ Desain Komunikasi Visual Department, School of Design, BINUS University \\ Jln. K. H. Syahdan No. 9, Palmerah, Jakarta Barat 11480 \\ dyah@binus.edu; jdarmawan@binus.edu
}

\begin{abstract}
The term 'signage' sometimes has been confused with the term 'sign or symbol', although the term signage is actually a theme which has consistency and also covers an area from a specific environment and mood. Signage has been designed to inform about location and direction of interior and exterior environment. In general, design system and the use of signage, such as graphic standard, material and the positioning, has been organized by international standardization from every country in the world. One of the most important categories of signage is the application of signage in highways. The study is about signage from historical background, category, color scheme, design and human factor approach; from psychological physics, social culture, to the connectivity with the value and products' characteristic. Human factor comprehension is also one of the most important elements in signage design process. Each perspective or perception from highway user and their reaction about the signage has been conditioned by a specific characteristic of human, such as from biophysics-psyche, socio-culture, spiritual cosmologis transcendental with its five senses. Human factor as a user has an important role to obtain the best solution or good design solution for the community who use that signage.
\end{abstract}

Keywords: signage, information, location, perception, message

\begin{abstract}
ABSTRAK
Istilah signage sering disalahartikan secara harafiah sebagai 'tanda', walaupun sebenarnya signage merupakan suatu tema yang konsisten dan meliputi suatu area dari sebuah lingkungan dan suasana yang dibangunnya. Signage dirancang untuk menginformasikan tempat dan arah baik dalam lingkup interior maupun eksterior.Secara umum, sistem perancangan dan penggunaan signage, seperti standar grafis, material dan penempatannya, diatur dengan standarisasi internasional yang disepakati bersama oleh berbagai belahan negara di dunia. Dari berbagai kategori signage, salah satu kategori yang penting adalah signage pada lokasi lingkungan jalan raya, dimana pada pembahasannya lebih dikhususkan pada signage jalan raya tol. Penjabaran signage dari sisi historis, kategori, skema warna, perancangan dengan pendekatan faktor manusia; baik dari sisi fisik psikologi, sosial dan kultur, hingga keterkaitannya dengan nilai dan karakteristik produk. Pemahaman faktor manusia juga merupakan salah satu unsur penting dalam perancangan signage. Setiap sudut pandang atau persepsi dari pengguna jalan dan tanggapannya terhadap signage dikondisikan oleh karakteristik khusus manusia, baik secara biophysics-pshyche, socio-culture, spiritual cosmologis transcendental dengan kelima inderanya. Faktor manusia sebagai pengguna memegang peranan penting dalam memperoleh solusi terbaik yang merupakan 'good design solution' bagi masyarakat pengguna signage tersebut.
\end{abstract}

Kata kunci: signage, informasi, lokasi, persepsi, pesan 


\section{PENDAHULUAN}

Pada masa sekarang ini signage sering diartikan secara harfiah sebagai tanda. Sebenarnyasignage bukan suatu kata yang benar-benar ada. Pada awalnya, kata signage digunakan oleh Paul Arthur, seorang pelopor "way finding” (penemuan jalan). Kata signage keluar ketika Paul Arthur mendiskripsikan "mindset” (cara berpikir), bahwa masalah komunikasi tempat, arah, kawasan dan lain-lain dalam suatu lingkungan tidak harus dilakukan secara verbal, namun dapat dipecahkan dengan menempatkan suatu tanda (sign). Pembahasan mengenai signage tercakup dalam keilmuan Environmental Graphic Design yang merupakan salah satu bagian dari keilmuan Desain Grafis yang khusus membahas dan merancang masalah signage.

Signage adalah suatu tema konsisten yang meliputi seluruh area dari suatu lingkungan berikut suasana yang dibangunnya. Signage harus mampu memberikan jawaban atas berbagai keperluan yang timbul dari masalah berbagai perbedaan bahasa dan persepsi pengamat.Signage harus dapat dimengerti melalui persepsi warna, visual, maupun verbalnya.

Berbagai macam signage telah dirancang untuk mengomunikasikan tempat, arah dan informasi lingkungan, baik untuk keperluan lokasi lingkungan dalam (misal: interior gedung perkantoran, rumah sakit, sekolah, museum, dll), maupun lokasi lingkungan luar (misal: jalan raya, kompleks perumahan, tempat rekreasi, dll). Adapun sistem perancangan dan penggunaannya secara umum, seperti standar grafis, material dan penempatan, diatur dengan standardisasi internasional yang disepakati berbagai belahan negara di dunia. Khusus mengenai signage jalan raya, pada tahun 1968 di Konvensi "Road Sign and Signals", Wina, Austria, telah disepakati sistem umum signage jalan raya yang diberlakukan di 52 negara di dunia. Namun untuk penerapan detailnya, masing-masing negara memiliki regulasi yang berbeda. Hal ini dapat dilihat misalnya pada sistem pengukuran yang digunakan setiap negara (contoh: Amerika dengan sistem mil, Indonesia dengan sistem meter), pembagian detail kategori signage, serta penggunaan bahasa.

Dari berbagai kategori fasilitas signage lokasi lingkungan jalan raya yang ada, kajian ini dibatasi pada pembahasan lingkungan jalan raya tol, dengan lokasi pendokumentasian di lingkungan jalan raya tol Bintaro. Pembahasan dijabarkan mulai dari pembahasan sisi historis signage, kategori, skema warna, perancangan dengan pendekatan faktor manusia, pemahaman faktor manusia dari sisi fisik psikologi, sosial kultural sampai dengan keterkaitan nilai dan karakteristik produk.

Tujuan dari kajian fasilitas signage jalan raya tol ini adalah untuk mendapat gambaran umum mengenai konsep perancangan signage yang diberlakukan di seluruh dunia yang diterapkan pada lokasi lingkungan jalan raya, khususnya jalan raya tol. Pengetahuan ini diharapkan dapat memberikan informasi tambahan, khususnya bagi desainer grafis yang merancang signage jalan raya, agar dapat merancang sesuai dengan ketentuan yang berlaku di seluruh dunia.

\section{METODE PENELITIAN}

Penulisan disusun menggunakan pendekatan studi literatur dan studi data dari jaringan elektronik yang dijadikan sumber informasi utama dari penelitian ini.Selain itu, penulis juga melakukan riset di lapangan dengan mengambil data imaji di jalan tol wilayah Bintaro yang memiliki beberapa contoh signage atau rambu yang ada di wilayah tersebut. Setelah itu, penulis juga mengembangkan data-data dan informasi yang ada dari sumber tersebut dengan menambahkan informasi lanjut yang berdasarkan pada pengamatan, hipotesis, dan pengembangan ide dari materi yang ada. 


\section{HASIL DAN PEMBAHASAN}

Tanda atau rambu jalan tertua adalah milestones atau tugu batu, yang memberikan informasi jarak dan arah; sebagai contohnya adalah kolom dari batu yang didirikan pada zaman Romawi pada saat kerajaan mereka memberikan jarak dan arah ke Roma. Pada abad pertengahan, tanda penunjuk berbagai arah di persimpangan jalan menjadi hal yang umum, yang berfungsiuntuk memberikan arah menuju ke kota dan desa.

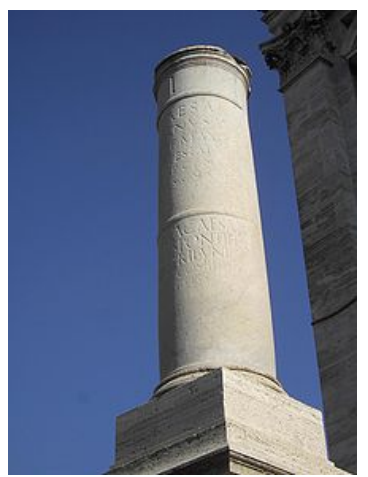

Gambar 1 Tugu batu penunjuk jalan bangsa Romawi

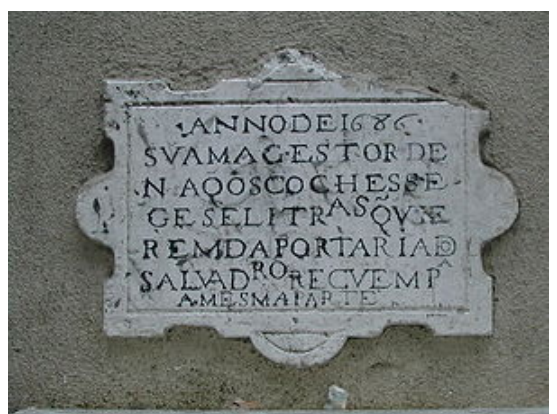

Gambar 2 Rambu lalu lintas dari abad ke-17 di Jalan Salvador, Alfama, Lisboa

Penunjuk jalan modern pertama yang didirikan dalam skala besar didesain bagi para pengemudi sepeda tinggi dan sepeda normal pada akhir1870-an dan pada awal 1880-an. Mesin-mesin sepeda ini bersifat cepat, tenang dan sifat dasarnya membuat mereka sulit untuk dikendalikan, terlebih lagi para pengendara menempuh jarak yang perlu dipertimbangkan dan mereka lebih suka melewati jalan-jalan yang tidak biasa. Untuk pengendara yang demikian, organisasi bersepeda mulai mendirikan tanda-tanda yang memberikan peringatan mengenai kemungkinan bahaya yang ada di depannya (umumnya bukit-bukit yang terjal), hingga penunjuk jalan tidak hanya berfungsi sebagai pemberi tanda jarak atau arah menuju ke suatu tempat. Hal ini menjadi kontribusi baru mengenai jenis tanda/rambu yang dikategorikan 'modern', dan selanjutnya menjadi tanda/rambu lalu lintas.

Perkembangan selanjutnya dari kendaraan otomotif menyebabkan lebih banyak sistem signage yang dibuat yang bersifat lebih kompleks, yaitu dengan mulai digunakannya bentu-bentuk tanda yang bukan sekedar kalimat pemberitahuan saja.Salah satu sistem sign modern diciptakan oleh Italian Touring Club pada 1895.Pada 1900, Congress of the International League of TouringOrganizations di Paris mempertimbangkan proposal untuk standarisasi signage khusus untuk jalan. Pada1903, pemerintah Inggris memperkenalkan tanda/rambu nasional yang berdasarkan dari bentuk, namun pola dasar dari hampir seluruh tanda/rambu yang ada baru dibuat pada tahun 1908 oleh International Road Congress di Roma. Pada 1909, sembilan pemerintah Eropa setuju untuk menggunakan empat simbol piktorial, yang mengindikasi 'guncangan', 'gelombang', 'persimpangan', dan 'tingkatan untuk jalur penyeberangan'. Pekerjaan yang intensif dari tanda/rambu jalan internasional yang diciptakan antara tahun 1926 dan 1949 menjadi pemicu perkembangan rambu jalan di Eropa. Inggris dan Amerika masing-masing mengembangkan sistem signage jalan di wilayahnya, yang selanjutnya kedua sistem tersebut diadaptasi dan dimodifikasi oleh banyak negara di belahan dunia. UK mengadaptasi versi dari rambu jalan Eropa pada1964 dan setelah melewati beberapa dekade, signage di Amerika Utara mulai menggunakan beberapa simbol dan grafis yang dipadukan dengan versi Inggris.

Setelah bertahun-tahun, perubahan terus terjadi secara bertahap. Sebelum masa revolusi industri tanda terbuat dari batu atau kayu. Namun dengan pengembangan dari metode Darby, yaitu 
dengan mencairkan besi menggunakan coke, mulai pada akhir abad ke delapan belas hingga abad ke sembilan belas, penggambaran tanda di atas lempengan besi menjadi populer. Lempengan besi terus digunakan hingga pertengahan abad ke dua puluh, namun perlahan-lahan keberadaannya digantikan oleh aluminium atau material lainnya dengan proses yang berbeda. Sejak tahun 1945, hampir seluruh tanda/rambu dibuat dari lempengan aluminium yang dilapisi oleh lapisan plastik. Hal ini akan memberikan efek memantul di malam hari namun masih agak sulit terbaca dengan cahaya yang kurang memadai. Hingga efek reflektivitas kemudian didukung dengan menggunakan pantulan dari kaca yang dipadukan pada pembuatan huruf dan simbol.Selanjutnya hal ini semakin mengalami penyempurnaan yaitu dengan adanya perkembangan plastik reflektif.

Generasi baru dari rambu lalu lintas berdasarkan pada tampilan elektronik yang juga dapat mengubah kalimat (atau mengubah simbol di beberapa negara) untuk mendukung 'kendali intelejensi' yang terkait secara otomatis pada sensor lalu lintas atau pengaturan yang dimasukkan secara manual. Di lebih dari 20 negara, peringatan siaran langsung melalui Traffic Message Channel ditayangkan secara langsung pada fasilitas untuk navigasi yang ada di kendaraan masing-masing dengan menggunakan signal dari radio FM, data telepon selular dan tayangan satelit. Akhirnya, mobil dapat melakukan pembayaran biaya tol dengan menggunakan sistem pemindai yang aman dengan menggunakan pindaian plat kendaraan, dan perkembangan sistem modern lainnya.

\section{Kategori Signage}

Signage jalan raya atau rambu lalu lintas dapat dikelompokkan menjadi beberapa jenis. Seperti yang tercantum pada Lampiran 1 dari Konvensi "Road Sign andSignals", Wina, Austria, tahun 1968, rambu lalu lintas dibagi menjadi delapan kategori tanda:Danger warning signs, Priority signs, Prohibitory or restrictive signs, Mendatory signs, Special regulation signs, Information, facilities, or service signs, Direction, position, or indication signs, danAdditional panels.

Seiring dengan perkembanganya jaman, pengategorian signage jalan raya atau rambu lalu lintas dikelompokkan menjadi sebagai berikut. Pertama, Oriental Signage. Signage ini bersifat melokasikan pengguna dalam sebuah lingkungan dan menginformasikan keberadaan tempat secara jelas dan berupa peta secara keseluruhan. Kedua, Informational Signage. Signageini memberikan informasi berupa instruksi tentangyang boleh dan tidakboleh dilakukan. Ketiga, Directional Signage. Signage yang berfungsi mengarahkan; merupakan navigasi yang paling penting.Meskipun bukan yang paling utama dalam sign system, cukup memengaruhi keseluruhan fungsi signage.Signage ini bersifat menunjukkan secara harfiah (misal: ke kiri, ke kanan, atas, bawah), yang secara umum menngunakan simbol anak panah. Keempat, Identificational Signage,yang menunjukkan identitas suatu gedung atau lokasi. Kelima, Stationary Signage; signage peraturan untuk menginformasikan larangan khusus pada suatu tempat yang biasanya digunakan khusus oleh pemilik atau pengelola suatu tempat. Peraturan atau larangan ini dimaksudkan untuk tindakan pencegahan dan perlindungan dari suatu bahaya tertentu,seperti peringatan hukum, peraturan keamanan, traffic control devices, pintu keluar darurat, dansebagainya. Keenam, Ornamental signage. Tujuan utama dari signage ini adalahuntuk menambah estetika dari suatu bangunan atau tempat, hingga dapat menghasilkan efek yang mengesankan pada suatu lingkungan.Contohnya adalah umbul-umbul, spanduk, bendera, dll.

\section{Skema Warna Signage}

Secara umum, negara-negara belahan dunia, termasuk Indonesia mengadopsi sistem skema warna signage jalan raya sistem Amerika sebagai berikut:Merah dengan putih untuk tanda berhenti dan tindakan terlarang, seperti dilarang parkir, dilarang masuk, dilarang berhenti, dll; Hijau denga huruf putih untuk tanda informasi, seperti arah, jarak dan tempat-tempat; Cokelat dengan putih untuk tanda tempat bersejarah,daerah ski dan tempat berkemah; Biru dengan putih tempat layanan seperti rumah sakit, rest area, bensin, penginapan, dll; Putih dengan hitam (atau merah) untuk tanda peraturan 
seperti batas kecepatan, dll; Kuning dengan huruf atau simbol hitam untuk tanda peringatan seperti jalan menurun, tanjakan, percabangan jalan, dll.

\section{Perancangan Signage dengan Pendekatan Faktor Manusia}

Pada dasarnya manusia adalah makhluk biophysics-psyche, socio culture, spiritual cosmologis transcendental dengan kelima inderanya.Oleh karena itu, setiap perancangan harus mengacu pada sifat karakteristik manusia sebagai pengguna.Demikian juga mengenai perancangan dari tanda, persepsi dari tanda dipengaruhi oleh faktor fisik dan psikologis, seperti kualitas penglihatan, kemampuan membaca, ingatan/memori, sensitifitas warna, dan sikap/kelakuan. Ketika semua keberagaman muncul dari individu masing-masing dan berada di luar kendali seorang desainer, maka ia sebaiknya memiliki pemahaman secara umum mengenai bagaimana faktor-faktor ini akan memengaruhi tanggapan dari pengguna jalan terhadap tanda.

Penduduk kota rata-rata telah dikondisikan oleh pendekatan tanda selama bertahun-tahun. Beberapa pengguna jalan mungkin akan memberikan tanggapan negatif ketika diperlihatkan terlalu banyak tanda, tetapi kebanyakan lebih bersikap netral terhadap rambu secara umum. Ada begitu banyak tanda yang akan ditanggapi oleh seseorang karena sudah menjadi kebiasaan. Ia akan memberikan reaksi dengan berhenti dan berjalan sesuai dengan tanda lalu lintas dan pada rambu lainnya sering tanpa disadari. Reaksi otomatis ini memberikan kesadaran yang lebih bebas untuk mengumpulkan informasi dan memberikan keputusan.

Pada saat seorang pengguna jalan mengendarai atau berjalan melewati kota untuk mencari informasi, ia akan mengamati lingkungan di sekitarnya. Tanda beserta dengan elemen-elemen lain yang berada di dalam wilayah pengamatannya akan dilihat secara umum dengan caranya sendiri, kecuali mereka membutuhkan informasi khusus. Maka mereka akan lebih fokus mencari informasi yang dibutuhkannya. Seorang desainer harus mengetahui reaksi dasar tersebut dan menyadari bahwa tanda yang dibuat untuk pengguna jalan tersebut bersaing dengan berbagai elemen lain di lingkungannya. Ketika sebuah lingkungan khusus dapat dikendalikan secara visual oleh seorang desainer, maka perhatian dari pengguna jalan terhadap sign system dan keefektivitasannya dapat ditingkatkan secara dramatis.

\section{Pemahaman Faktor Manusia}

Setiap sudut pandang atau persepsi dari pengguna jalan dan tanggapannya terhadap tanda dikondisikan oleh karakteristik khusus manusia secara biophysics-psyche, socio culture, spiritual cosmologis transcendental dengan kelima inderanya. Oleh karena itu, setiap perancangan harus mengacu pada apa yang disebut sebagai faktor manusia.

\section{Faktor Fisik}

\section{Wilayah Penglihatan secara Normal (Normal Field of Vision)}

Ilmu pengetahuan mengindikasi bahwa wilayah penglihatan normal atau sudut pandang yang sesuai untuk tanda berada pada sudut pandang $60^{\circ}$. Area di luar sudut pandang tadi tidak efisien karena akan terlihat kurang detail. Ketika benar adanya bahwa wilayah penglihatan dapat diperluas dengan menengokkan atau mendongakkan kepala, rata-rata pengguna jalan menolak untuk memberikan usaha yang lebih demi melihat sesuatu di luar sudut pandangnya. Sebagai contoh, bila sebuah tanda diletakkan pada langit-langit yang tinggi sehingga garis pandang penglihatan dari mata pengguna jalan hingga titik horisontalnya mencapai lebih dari $30^{\circ}$, hal ini akan mempersulit atau berlebihan. Umumnya, para pengguna jalan tidak memiliki kebiasaan untuk mendongakkan kepala mereka untuk melihat tanda, mereka juga tidak akan menggerakkan kepala mereka di luar kebiasaan 
untuk melihat sesuatu secara khusus di luar sudut pandang mereka. Konsistensi dari ketinggian tanda yang dibuat pada sistem akan mempermudah pengguna jalan untuk melihat untuk mencari informasi di berbagai tempat.

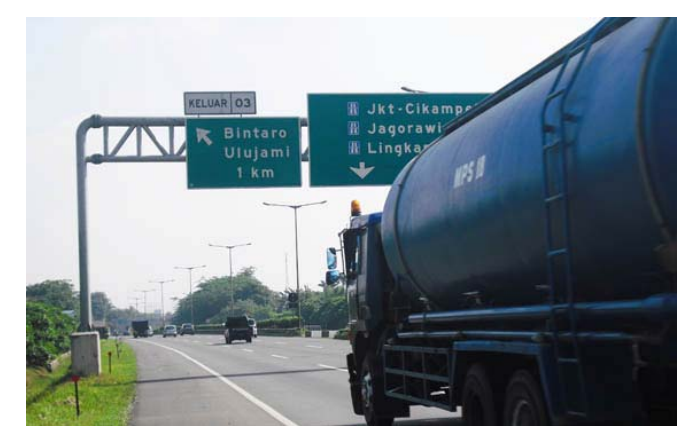

Gambar 3 Konsistensi Ketinggian Signage Jalan Raya

\section{Ketajaman Visual (Visual Acuity)}

Pengguna jalan mengamati berdasarkan kemampuan mereka untuk melihat secara jelas.

\section{Kecepatan Membaca (Reading Rate)}

Dari semua kemampuan umum membaca, ada begitu banyak kecepatan membaca dari masing-masing pengguna jalan. Dari seseorang dengan kecepatan membaca sekitar 125 kata per menit, hingga 500-600 kata per menit.Faktor-faktor seperti umur, kepandaian, dan pendidikan memengaruhi kecepatan membaca. Rata-rata kecepatan membaca pada umumnya adalah 250 kata per menit. Berdasarkan pada kecepatan membaca ini, tanda sebagai pengantar atau penyampai pesan yang hanya dapat dilihat sepersekian detik saja, sebaiknya tidak memuat lebih dari enam sampai delapan item singkat.

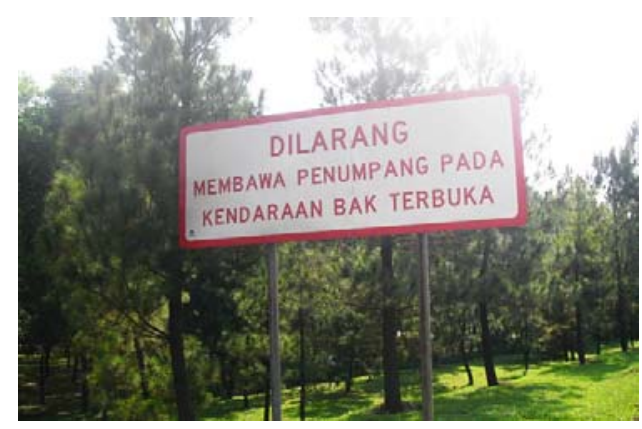

Gambar 4 Penyampaian pesan dengan batas maksimal jumlah item singkat

\section{Keterbacaan (Legibility)}

Studi tentang jarak mengindikasi bahwa di bawah cahaya matahari normal, seseorang dengan kemampuan melihat 20/20 dapat melihat huruf setinggi 1 inci (25 milimeter) sesuai dengan standar tabel Snellen yang digunakan oleh optometris pada jarak 50 kaki (15 meter). Akan tetapi, laboratorium ideal seperti ini harus dimodifikasi untuk keterbacaan desain tanda. 


\section{Ketinggian Penglihatan Mata (Eye Level)}

Rata-rata ketinggian dari penglihatan seseorang diukur dari tanah ketika ia berdiri adalah sekitar 5 kaki, 6 inci (1.7 meter); ketika sedang duduk, ketinggian penglihatannya adalah sekitar 4 kaki, 3 inci (1.3 meter); ketika sedang mengemudi kendaraan, ketinggian penglihatannya adalah sekitar 4 kaki, 6 inci (1.4 meter). Ketinggian penglihatan mata dari seorang pengguna jalan yang sedang mengendarai mobil truk jauh lebih tinggi dari pada seorang pengemudi mobil biasa dan sebaiknya disesuaikan dengan kendaraan-kendaraan khusus yang berkaitan dengan masalah tanda yang akan didesain.

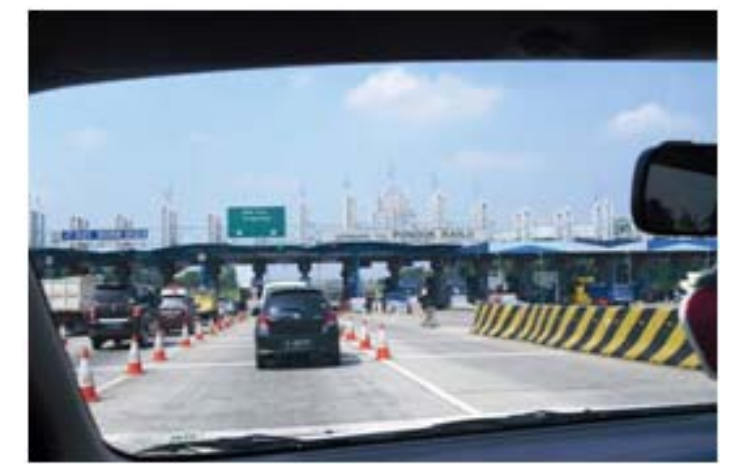

Gambar 5 Area penglihatan pengendara dari dalam mobil

\section{Ketinggian Kata (Letter Heights)}

Di dalam menentukan salinan ketinggian huruf untuk tanda khusus kendaraan melibatkan faktor-faktor tambahan: terutama kecepatan laju kendaraan dan waktu yang dibutuhkan untuk mengenali dan membaca tanda.

\section{Peninjauan Kebutuhan dari Usia Lanjut dan Orang-orang Kurang Mampu secara Fisik (Meeting Needs of Aging and Physically Disabled People)}

Pada era bertambahnya populasi usia lanjut dan orang-orang cacat secara fisik, fasilitas umum yang digunakan oleh mereka meningkat jangkauan kebutuhannya. Untuk memenuhi kebutuhan umum, maka jangkauan penglihatan untuk ketinggian huruf berkisar dari 1 inci hingga 25 kaki (7.5 meter), berdasarkan huruf kapital jenis Helvetica. Hal ini disesuaikan dengan panduan lebih praktis untuk tanda bagi pejalan kaki.

\section{Faktor Psikologis}

\section{Hubungan Dasar Bentuk (Figure-Ground Relationship)}

Para psikolog mengacu pada hubungan dasar bentuk. Mereka membicarakan mengenai bentuk dan pola dilihat berdasarkan latar belakangnya. Bentuk digambarkan oleh sisi, dan sisi merupakan persepsi dari garis batas/kontur. Apapun yang berpengaruh terhadap persepsi jelas dari garis batas/kontur akan memberikan efek pula untuk pengenalan objek. Konsep dasar bentuk juga berkaitan dengan jarak negatif antara huruf ke huruf memberikan pengaruh pada persepsi dan pengenalan bagi huruf dan bentuk. Pada saat memahami proses membaca, kita secara sadar menyusun huruf-huruf tersebut menjadi kata-kata. Kita juga mempelajari bagaimana memisahkan seluruh kata-kata tersebut berdasarkan bentuknya. Para psikolog menyebutnya 'pengisian persepsi' (perceptual filling in) atau 'pengaturan bentuk' (figural organization). Apabila huruf-huruf dikumpulkan bersama sehingga 
mereka saling berdekatan atau terpisah secara berlebihan, jarak negatif dapat memengaruhi titik tertentu yang pengenalan terhadap sebuah kata secara keseluruhan akan berantakan.

\section{Implikasi Warna (Implications of Color)}

Para individu biasanya memiliki pertimbangan yang beragam pada kemampuan mereka untuk memisahkan dan mengingat warna. Kemungkinan hanya ada enam warna yang berbeda, tidak termasuk putih dan hitam - merah, kuning, biru, hijau, tangerine/oranye, cokelat - yang dapat dipisahkan dengan mudah dan diingat oleh orang normal. Di luar dari keterbatasannya, warna dapat digunakan sebagai elemen kedua untuk mengidentifikasi atau sebagai alat/sarana untuk mengirimkan tanda/sandi (coding) pada situasi tertentu dimana jumlah warna yang digunakan sangat terbatas.Sebagai contoh, warna biasanya digunakan untuk mewarnai kolom atau dinding pada lahan parkir untuk mempermudah identifikasi tingkat atau lantai yang berbeda. Aplikasi penanda ini tidak membutuhkan ingatan warna ketika digantikan oleh angka dan huruf.

Warna dapat membangkitkan mood atau perasaan tertentu; kualitas warna yang positif ini biasanya banyak digunakan pada grafis dinding, desain interior, dan pencahayaan. Warna-warna tertentu dapat menjadi cara yang memberikan pengaruh kuat pada tanda; seseorang telah dikondisikan untuk memahami bahwa warna-warna tertentu, merah misalnya, merupakan pertanda dari bahaya atau darurat karena pengalaman dari mesin api, lampu merah yang berkedip, atau tanda lalu lintas. Warna merah digunakan sebagai latar belakang dari tanda berhenti hampir di semua negara, warna merah telah dikondisikan sebagai penanda untuk perintah 'berhenti' (stop), namun tidak dapat digunakan secara khusus sendiri untuk tempat berhenti. Sama kasusnya dengan reaksi kita melihat warna kuning sebagai warna peringatan, mungkin karena kita sudah terbiasa melihatnya selama bertahun-tahun digunakan sebagai tanda lalu lintas dan tanda di wilayah konstruksi.

Aplikasi khusus dari warna menghasilkan fenomena visual yang menarik ketika digunakan pada seni optik (op-art) atau grafis, namun menjadi masalah ketika digunakan pada sistem penandaan. Ketika dua warna komplementer dengan kekuatan intensitas warna yang sebanding digunakan secara bersamaan, maka dalam kasus huruf dan latar belakang, akan terjadi kebingungan terhadap maksud yang ingin disampaikan.
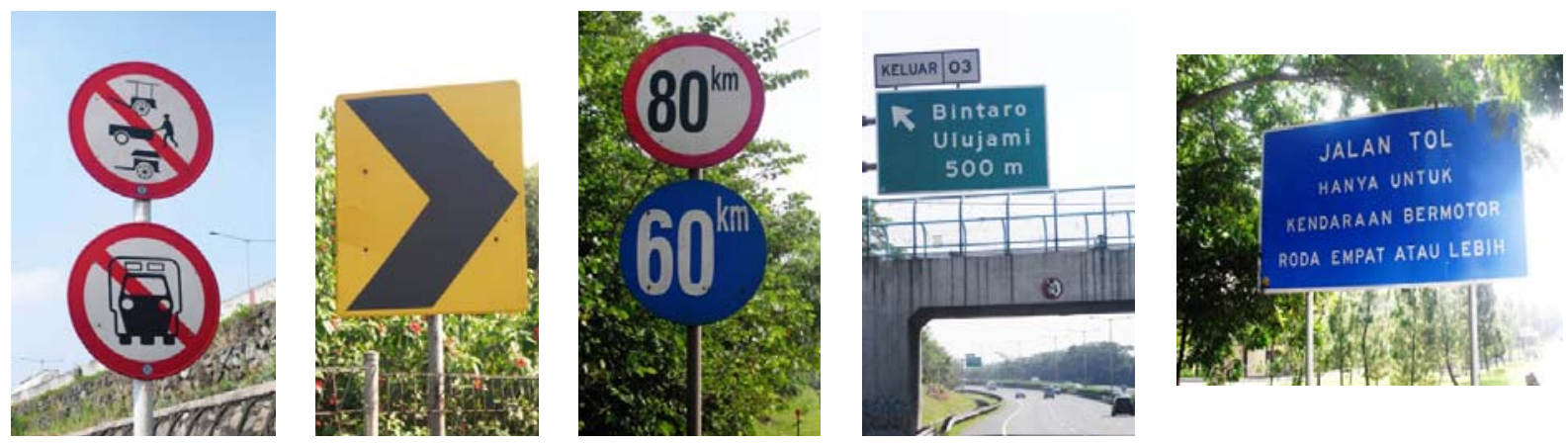

Gambar 6 Berbagai Figure-ground dan Implikasi Warna dalam Signage Jalan Raya

\section{Faktor-faktor yang Memengaruhi Persepsi}

Ada sejumlah faktor-faktor lingkungan yang memengaruhi bagaimana seseorang akan memahami tanda khusus. Yang terpenting adalah bahwa hal ini berkaitan dengan kualitas, intensitas, dan warna dari cahaya sekitarnya yang jatuh pada tanda tersebut; gangguan secara fisik dari garis penglihatan antara pengamat dan tanda; serta lingkungan visual yang ada di belakang atau sekitar tanda tersebut. 
Untuk beberapa bagian terpenting, faktor-faktor lingkungan ini di luar kendali dari desainer, akan tetapi mereka terkait dengan faktor-faktor desain yang sebenarnya dapat dikendalikan. Pencahayaan buatan dapat digunakan untuk meningkatkan persepsi tanda. Tanda dapat digantikan untuk meningkatkan garis pandang. Hampir semua elemen desain dari tanda dapat dikurangi untuk meningkatkan keterbacaan tanda, sebagai kompensasi untuk mengimbangi lingkungan visual yang kurang memadai’.

\section{Pencahayaan Sekitar (Ambient Lighting)}

Pencahayaan normal yang berada di lingkungan sekitar, atau disebut dengan ambient lighting merupakan pertimbangan utama.Tingkat pencahayaan lingkungan sekitar yang ditemukan oleh kebanyakan pengamat untuk menemukan tanda yang tidak bercahaya (nonilluminated sign) adalah minimal 25 cahaya lilin. Akan tetapi untuk melihat tanda eksterior yang tidak bercahaya (nonilluminated sign) di malam hari, cahaya sekitar yang dilihat adalah sekitar 2 buah cahaya lilin saja, akibat dari kemampuan dari pengamatan mata yang berkurang di kegelapan.

Sejalan dengan menurunnya tingkat cahaya sekitar, maka kontras antara kata-kata dan latar belakang tanda akan bertambah. Pada tanda yang tidak bercahaya (nonilluminated sign). Hal ini dapat dicapai dengan menggunakan kata-kata dengan warna terang di atas panel yang gelap, atau kebalikannya. Jika tulisan atau latar belakang tanda akan dibuat kembali dengan warna, seorang desainer sebaiknya melakukan tes terlebih dahulu untuk warna yang akan digunakan sesuai dengan tempat penggunaannya, agar lebih meyakinkan dan pasti. Pesan yang ditulis dengan warna putih di atas latar belakang warna kuning muda dimana cahaya sekitarnya rendah, tentunya akan mengakibatkan ketidakterbacaan akibat kurangnya kontras warna. Tulisan berwarna putih di atas latar belakang hitam atau kebalikannya akan menghasilkan kontras warna yang baik dan mudah untuk dibaca dengan cahaya secukupnya. Di luar dari kontras tulisan dan latar belakang, penelitian juga mengindikasi bahwa ketajaman visual dapat meningkat secara keseluruhan dengan meningkatnya tingkat pencahayaan.Selain itu juga, kecepatan seseorang untuk mengenali tanda dan tulisan tanda meningkat seiring dengan meningkatnya pencahayaan. Akan tetapi, warna-warna cerah yang diletakkan di atas tanda berwarna akan mengurangi keterbacaan bila kontrasnya hanya sedikit antara tulisan dan latar belakang.

Bila cahaya sekitar masih kurang memadai, tanda dapat dibuat lebih terbaca dengan pencahayaan dari dalam. Hal ini tentunya sangat dibutuhkan untuk tanda eksterior yang dibaca pada malam hari bila tidak ada sumber cahaya lain di sekitarnya atau bila hal tersebut dibutuhkan untuk membuat tulisan lebih menyolok atau dramatis. Akan tetapi, pencahayaan dari dalam yang berlebihan dapat mengurangi keterbacaan dengan menciptakan 'halo effect' dari huruf-huruf terang di atas latar belakang gelap. Fenomena visual ini akan membuat huruf-huruf tampak lebih besar atau lebih besar pada malam hari daripada siang hari. Hal ini dapat diperbaiki dengan mengurangi intensitas dari sumber cahaya dalam atau memodifikasi lebarnya huruf, atau bisa juga mengkombinasi keduanya.

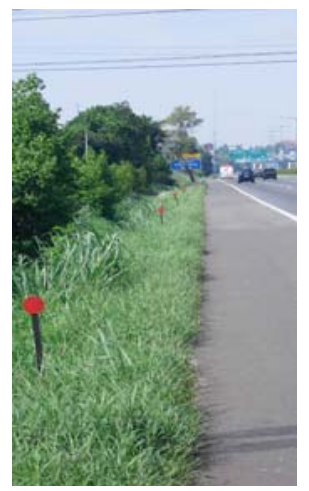

Gambar 7 Spot merah sepanjang pinggiran jalan sebagai illuminated sign 


\section{Garis Penglihatan (Sight Lines)}

Dasar dari faktor manusia lebih dipentingkan pada peletakan tanda tersebut pada ketinggian penglihatan mata (eye-level) rata-rata. Hal ini jelas terlihat pada tanda bagi pejalan kaki yang diletakkan sesuai dengan tingkat penglihatan mereka. Akan tetapi, hal tersebut merupakan jawaban dasar untuk mempermudah masalah yang ada. Hal yang terpenting adalah untuk mengingat bahwa tanda seharusnya diletakkan untuk menghindari gangguan garis penglihatan normal. Seorang desainer harus memiliki empati, mencoba untuk meletakkan dirinya di posisi pengamat/pengguna tanda tersebut. Ia harus mempertimbangkan masalah tanda satu persatu sesuai dengan kegunaannya. Beberapa pertanyaan yang harus dipertimbangkan adalah: Apakah tanda tersebut dapat dilihat oleh orang lain secara umum di luar pengamat dengan tinggi rata-rata? Apakah tanda tersebut dapat lihat dari sudut pandang tertentu hingga garis penglihatan normal? Apakah tanda tersebut berada di luar wilayah penglihatan normal? Apakah latar belakang dari tanda tersebut, bagaimana dengan lingkungan sekitarnya, pencahayaannya? Apakah tanda-tanda lainnya atau ciri khas arsitektur di sekitarnya akan memengaruhi garis penglihatan dari pengamat? Apakah pohon-pohon atau unsur alam lainnya akan tumbuh dan berkembang sehingga nantinya akan mengganggu tanda yang diletakkan di sana? Apakah kendaraan yang diparkir akan mengganggu tanda yang dipasang tersebut pada waktuwaktu tertentu? Apakah tanda dapat dilihat oleh baik pengemudi kendaraan maupun pejalan kaki dan dapat dibaca oleh keduanya? (tingkat ketinggian penglihatan seorang pengemudi kendaraan tentunya berbeda dengan pejalan kaki)
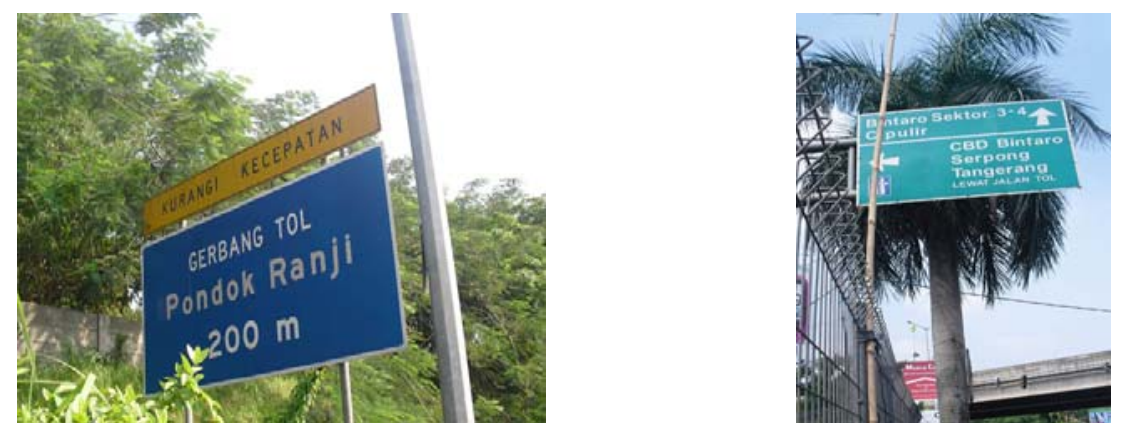

Gambar 8 Unsur alam dan lingkungan perlu dipertimbangkan guna menghindari gangguan penglihatan pengendara

\section{Latar Belakang Tanda}

Ada beberapa kondisi latar belakang yang dapat memengaruhi persepsi. Salah satunya adalah permukaan dinding dimana huruf satu persatu dituliskan, sesuai dengan penjelasan sebelumnya pada 'Hubungan Dasar-Bentuk' (Figure-Ground Relationship). Kondisi lainnya dapat merupakan pengalihan pemandangan di balik panel tanda yang dipasang secara bebas. Hal ini juga dapat mengakibatkan keterlibatan visual dengan pesan tanda, kecuali bila panel tanda didesain sesuai dan cukup besar untuk mengalihkan pesan dari pengalihan visual lainnya.

Bayangan yang jatuh oleh karena tekstur kasar yang dihasilkan oleh cahaya matahari akan menghasilkan pola, dan cover dinding yang dicetak juga dapat menghasilkan efek yang hampir sama. Seorang desainer sebaiknya membiasakan diri untuk menghindari penggunaan pemotongan huruf sambung yang ditulis pada pola wallpaper gulungan, karena huruf tersebut akan bertabrakan dengan latar belakang untuk menarik perhatian. Salah satunya harus menghindari penggunaan huruf dari jenis tertentu agar tidak berlawanan dengan pola geometris (seperti garis-garis hitam dan putih); pola seperti itu dapat mengakibatkan visual vibration yang akan mengurangi unsur keterbacaan huruf. Untuk keterbacaan secara optimal pada pemasangan tanda, yang dimana sering terlihat berlawanan dengan 
latar belakang yang membingungkan, sebuah panel tanda atau dinding yang sederhana akan menciptakan latar belakang yang positif untuk bentuk huruf.

\section{Pesanan Tanda dapat Memengaruhi Persepsi}

\section{Simbol dapat Bersifat Ambigu}

Secara mayoritas, manusia lebih berorientasi verbal atau lisan, menyerap hampir seluruh informasi melalui kata-kata, dengan sebagian kaum minoritasnya lebih cepat bereaksi pada tanda visual seperti simbol. Hal ini mengindikasi bahwa hampir semua sign system membutuhkan pesan secara verbal. Fasilitas di lokasi jalan raya sering menggunakan simbol untuk memperkuat pesan secara lisan atau agar bisa berdiri sendiri. Jika simbol digunakan berdiri sendiri, sebaiknya simbol tersebut dapat diterima secara umum atau menyeluruh.

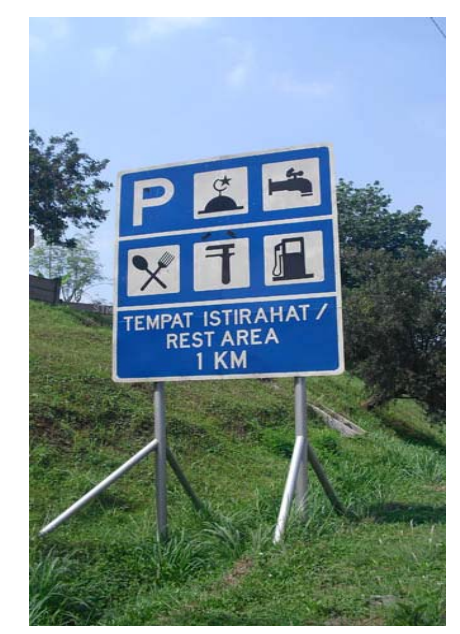

Gambar 9 Contoh penggunaan beberapa simbol pada signage jalan raya tol

Tanda panah sering digunakan untuk menggantikan kata pada tanda penunjuk, dan kita telah dikondisikan untuk bereaksi pada tanda penunjuk yang menggunakan tanda panah. Berdasarkan pada kebiasaan, kita dapat mengerti dengan jelas sebuah tanda yang bertuliskan 'restroom,' yang diikuti oleh sebuah tanda panah yang menunjuk ke arah kamar kecil (restroom). Namun tanda panah dapat bersifat ambigu pula. Sebuah bangunan dengan beberapa lantai, seperti rumah sakit, biasanya mengharuskan tanda penunjuk arah yang tergantung di langit-langit. Di sebuah persimpangan koridor, tanda panah mengindikasi arah kanan dan kiri dapat dimengerti dengan jelas; kesulitannya akan muncul ketika penunjuk arah 'terus' (ahead) juga ditunjukkan dengan tanda panah. Ketika tanda tersebut berada di arah yang tepat mengikuti alur, beberapa desainer membuat tanda panah turun, sedangkan beberapa orang lainnya menunjukkan arah sebaliknya (tanda panah naik). Akan muncul kebingungan tentang bagaimana menentukan arah yang benar - panah ke atas atau panah ke bawah khususnya bila ada anak tangga, escalator, atau elevator yang berada disekitarnya, karena hal ini bisa menimbulkan pemahaman yang berbeda bagi pengguna tanda. Mereka dapat mengartikannya berbeda, bukan arah lurus (terus) namun dianggap ada di lantai atas atau lantai berikutnya. Tampaknya hampir semua pengguna rambu telah memahami bahwa tanda panah yang menunjuk ke arah bawah mengindikasi 'turun' di satu situasi tertentu dan 'lanjut' pada situasi lainnya. Penggunaan tanda panah pada signage jalan raya tol umumnya digunakan sebagai pemandu batas jalur jalan, pemandu arah tempat, peringatan jalur bercabang, arah jalur dalam beberapa jalur yang biasa terdapat di area gerbang tol, dan arah putar balik di berbagai area khusus jalan raya tol. 

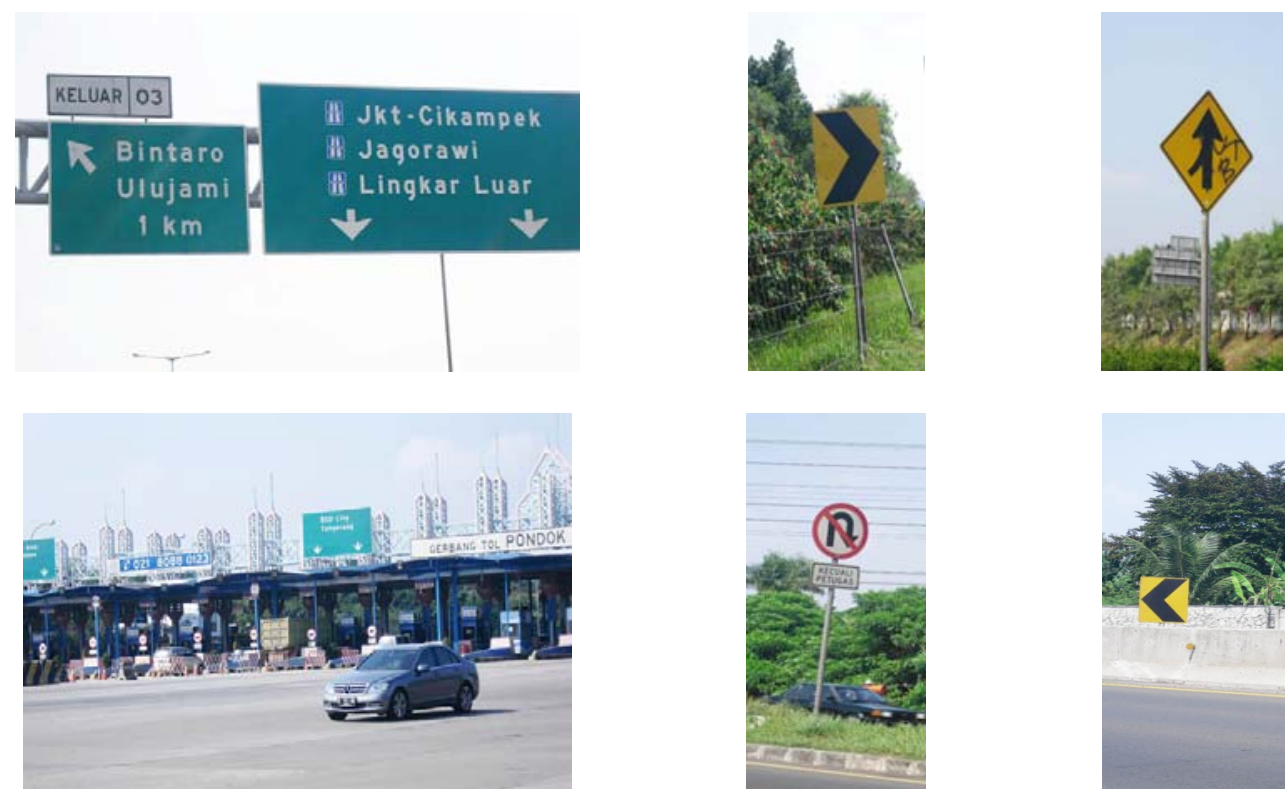

Gambar 10 Contoh pengggunaan beberapa tanda panah di lokasi jalan raya tol

\section{Tulisan Kata-kata}

Karena adanya beberapa kalimat khusus yang bersifat ambigu atau menjadi subyek untuk interpretasi pribadi, harus diciptakan kriteria tertentu untuk mengurangi kemungkinan tanda yang menyesatkan. Untuk memperjelas sign system agar lebih mudah dimengerti, beberapa kriteria yang harus dicantumkan pada tulisan adalah: Konsisten, Sesingkat mungkin agar lebih mudah untuk dibaca, Memiliki sama arti bagi siapapun yang membacanya (tidak bersifat ambigu), Menyampaikannya dengan positif.
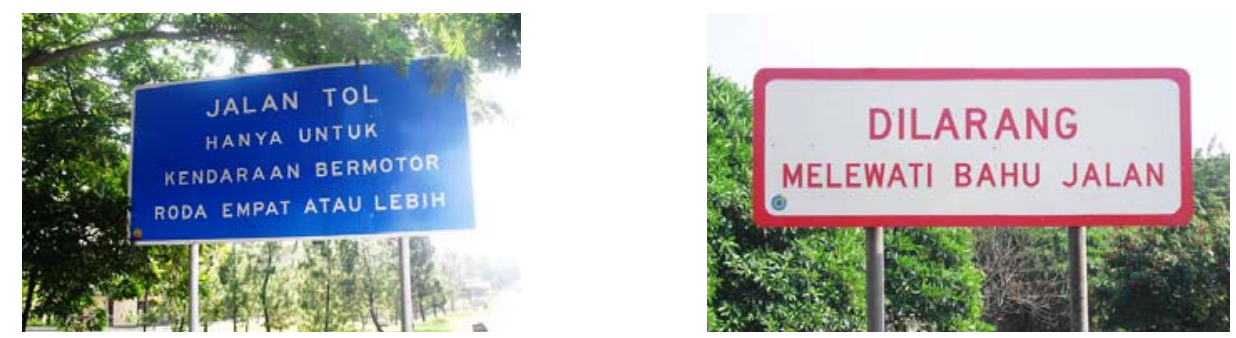

Gambar 11 Pesan tulisan yang singkat dan jelas dalam signage jalan raya tol

Dengan mempertimbangkan cakupan luas dari faktor manusia yang dibahas di bab ini, seorang desainer akan segera menyadari bahwa tidak ada sign system yang dapat disampaikan sama persis untuk semua orang. Akan tetapi, kendala yang dipaksakan oleh batasan faktor dan lingkungan akan membantu menjelaskan masalah penandaan tersebut, dan target yang spesifik dari sistem tersebut didesain agar mudah tersampaikan.

\section{Keterbacaan dari Tanda yang Ditujukan bagi Pengendara}

Keterbacaan dari tanda yang dilihat dari kendaraan yang sedang bergerak ditentukan oleh beberapa hal yang tercantum berikut sesuai dengan urutan prioritasnya: (1) Kecepatan berkendara dan jumlah dari jalur lalu lintas, keduanya dipengaruhi oleh kecepatan waktu. (2) Penentuan jarak 
peletakan tanda agar dapat dikenali dengan mudah. (3) Klasifikasi lingkungan (wilayah komersial, industri, perumahan, atau pertanian). (4) Jarak penglihatan, di antara sudut pandang atau di luar sudut pandang. (5) Pertimbangan dari segi desain grafis, seperti jenis huruf yang dipilih; jarak antarhuruf; jumlah kata yang digunakan, penamaan, atau tanda per suku kata; warna; jumlah kata untuk informasi yang disampaikan (sebaiknya tidak lebih dari enam); wilayah dari tanda muka secara keseluruhan; pencahayaan dan sumber cahaya; dan pengelompokan lainnya, serta elemen desain dasar.

Hal yang paling penting untuk dipertimbangkan di dalam mendesain tanda/rambu untuk pengendara adalah: jarak tanda untuk menentukan unsur keterbacaan ketika kendaraan diparkir; dan kecepatan waktu bereaksi pada saat kendaraan sedang melaju - waktu yang dibutuhkan oleh pengendara untuk melihat tampilan yang ingin disampaikan, membaca pesan, dan tanggapan terhadap pesan tersebut.

Hasil penelitian terdahulu dengan melakukan percobaan di lapangan telah menunjukkan bahwa waktu yang dibutuhkan oleh pengendara untuk melihat tanda, membaca, dan menanggapinya terkait dengan jumlah jalur lalu lintas sebagai berikut: 2-jalur jalan, 8detik; 4-jalur jalan, 10detik; 6jalur jalan, 11detik; jalan bebas hambatan, 12 detik. Semakin cepat sebuah mobil melaju, semakin jauh jarak tempuhnya ketika pengendara bereaksi terhadap pesan, maka semakin besar pesan tersebut harus dibuat. Hal tersebut telah dibuktikan dengan baik bahwa setiap jarak 50 kaki (15 meter) terpisah dari pengamat ke objeknya, maka tinggi huruf yang dibutuhkan adalah 1 inci (2.5 milimeter). Untuk lebih yakin agar tanda dapat dibaca, maka huruf kapital Helvetica setinggi 1 inci direkomendasikan untuk setiap jarak 30 kaki (9 meter).

Dikarenakan adanya batasan sampai mana seseorang dapat melihat dan mengingat pada saat ia sedang berkendara, maka jumlah informasi yang ingin dikomunikasikan padanya pada saat ia sedang berkendara di jalan menjadi sangat penting. Hal dan informasi tersebut disampaikan dalam bentuk simbol, kata, huruf, atau bentuk yang tertentu. Secara maksimal, untuk informasi, enam hal saja sudah lebih dari cukup untuk membantu pengendara melihat apa yang dibutuhkan. Terlebih lagi, enam hal tersebut sudah lebih dari cukup untuk digunakan dan diserap oleh pengendara dari sebuah tanda/rambu jalan.

Contoh dari kasus ukuran tanda atau rambu yang dibutuhkan terkait dengan kecepatan dan jarak tempuh dapat dilihat di skema berikut.

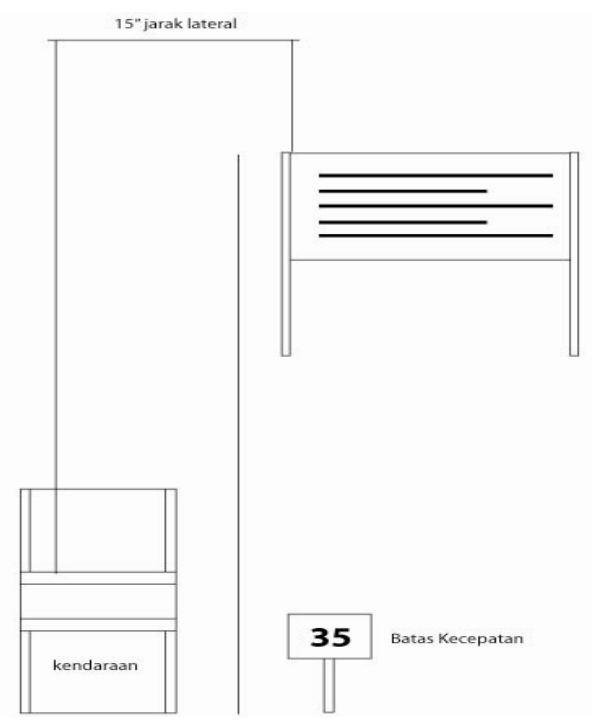

Gambar 12 Contoh ukuran tanda/rambu yang dibutuhkan terkait kecepatan dan jarak tempuh 


\section{Tinggi Huruf}

Sebagai tambahan untuk pemilihan jenis huruf, jarak, dan penggunaan huruf besar, ketinggian huruf juga bergantung pada jumlah kalimat atau baris kata, kecepatan yang terkait dengan jarak tempuh kendaraan, dan jarak lateral antara pengamat dengan tanda. Sebagai contohnya, ada tiga baris kalimat, batas kecepatannya adalah 35 mil per jam, dan jarak lateral adalah 15 kaki (4.6 meter). Untuk menghitung tinggi huruf yang dibutuhkan, ikuti langkah-langkah berikut: (1) Tambahkan angka 6 pada jumlah kata atau baris kalimat, $3+6=9$. (2) Kalikan dengan batas kecepatan yang diperoleh dari langkah pertama, 35 x $9=315$. (3) Bagi 100 dengan angka yang diperoleh dari hasil perkalian langkah kedua, $315 / 100=3.15$. (4) Bagi 10 dengan jarak lateral, $15 / 10=1.5$. (5) Tambahkan hasil yang diperoleh pada langkah ketiga dan keempat, $3.15+1.5=4.65$. (6) Hasil ini merupakan perkiraan minimum dari tinggi huruf yang harus digunakan, 4.65”. (7) Bila dibutuhkan, tinggi huruf dapat dibulatkan ke angka terdekat (pembulatan ke atas atau pembulatan ke bawah), 5” atau 4.5”.

\section{Faktor sosial kultur}

Terdapat berbagai perbedaan sistem pelaksanaan penempatan signage sisi lalu lintas di berbagai negara yang dipengaruhi oleh aspek sosial kultural dari masing-masing negara. Sebagai contoh dapat dilihat di berbagai negara seperti Amerika, Eropa, sebagai bangsa dengan mayoritas masyarakatnya beraktivitas dengan dominasi tangan kiri, hal ini berpengaruh pada tatanan perancangan produk otomotif dan pelaksanaan sistem lalu lintasnya. Jalur lalu lintas yang digunakan adalah jalur kanan, hingga sisitem signage sisi jalan raya ditempatkan pada sisi kanan jalan raya. Lain halnya dengan kondisi lalu lintas di Indonesia. Mayoritas masyarakatnya beraktivitas dengan dominan tangan kanan, lebih menerapkan sistem lalu lintas dengan pengggunaan jalur kiri, hingga penempatan signage sisi diletakkan di sisi kiri jalan raya.
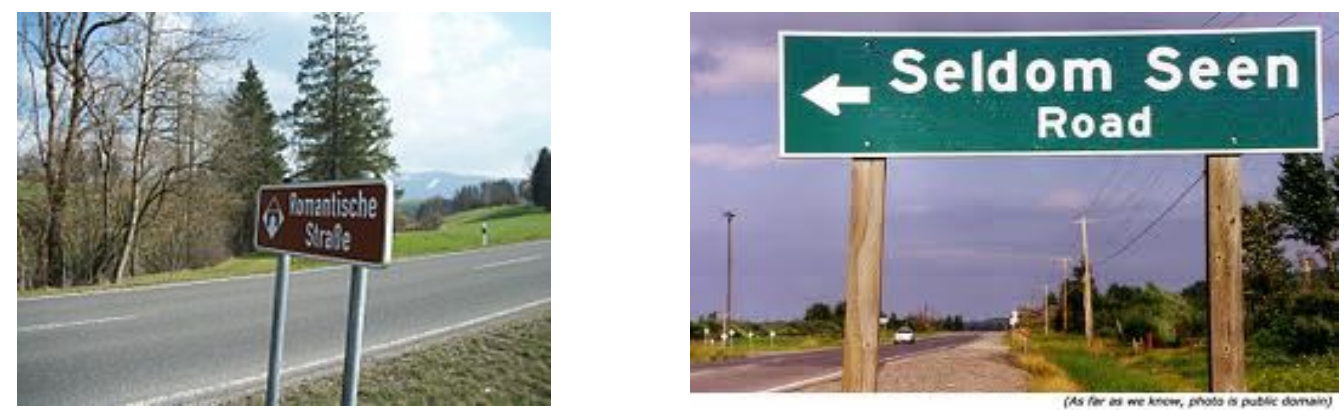

Gambar 13 Sistem penempatan signage sisi di sisi kanan jalan raya di salah satu kota di Jerman dan Alaska, Amerika

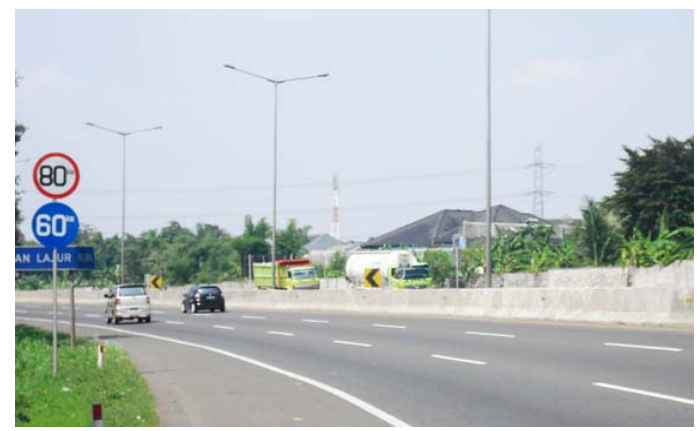

Gambar 14 Sistem penempatan signage sisi di sisi kiri jalan raya, di jalan raya tol Bintaro 


\section{Nilai karakteristik produk}

Karakteristik setiap produk memiliki diferensiasi nilai/value. Hal ini sangat dipengaruhi oleh perbedaan kondisi, kepentingan, dan waktu suatu produk tersebut digunakan. Perkembangan dan perubahan waktu mampu mengubah tampilan dan karakteristik dari suatu produk. Hasil elaborasi antara teori Mayall dengan teori Ahadiat, hubungan antara value dan karakteristik produk dapat dibagi menjadi tiga tingkatan, yaitu tingkat Essential, Important dan Desirable. Untuk selanjutnya, ketiga tingkatan ini dibandingkan dengan aspek muatan artefak dari suatu produk dan aspek sifat-sifat manusianya.

Berdasarkan teori tersebut di atas, signage jalan raya merupakan suatu produk dengan tingkat value Essential dan Important yang tinggi, tidak demikian untuk tingkat Desirable. Demikian juga untuk tingkat fungsi praktis utiliter dan nilai-nilai simbolik berada di tingkatan tinggi dengan ekspresi estetik yang cukup mendukung. Pada aspek sifat-sifat manusia, produk ini sangat berkaitan erat dengan ketiga faktor manusia, yaitu faktor biophisic, psycho dan socio culture.

\section{SIMPULAN}

Berdasarkan semua bahasan yang ada, maka dapat semakin dipahami bahwa suatu perancangan fasilitas objek pada suatu lingkungan tertentu senantiasa harus mengacu pada faktorfaktor yang menjadi substansi-substansi penting dalam proses pertimbangan, perencanaan dan perancangannya.

Faktor manusia sebagai pengguna memegang peranan penting dalam perolehan solusi terbaik berupa "good design solution" untuk masyarakat pengguna. Hubungan interaksi dengan berbagai unsur seperti ekologi, topografi, dan budaya sangat terkait dengan masalah manusia itu sendiri sebagai mahluk bio physics, psychologis, socio cultursl spiritual transcendental. Hal ini berpengaruh pada tingkat keterkaitan nilai dan karakteristik suatu objek.

Signage jalan raya sebagai penginformasi dan pengarah manusia di lingkunagn jalan raya harus mampu menginformasikan secara jelas dan tepat setiap pesan yang ingin disampaikan. Pemahaman aspek grafis, rancang bentuk, warna, penempatan, kondisi lingkungan dan pengguna harus dipahami dan diselaraskan dengan baik. Tingkat Essential dan Important yang mencakup fungsi utiliter praktis, nilai simbolik sangat memegang peran, disertai pula dengan kelayakan ekspresi estetik sebagai faktur pendukung. Standardisasi internasional yang telah ditetapkan sebaiknya dapat menjadi acuan perancangan sistem signage.

Sehingga dapat disimpulkan bahwa suatu perancangan signage jalan raya yang baik adalah yang mampu mengatasi masalah informasi, komunikasi di lingkungannya, dimana proses perancangannya harus melalui suatu pertimbangan yang holistik , mulai dari pertimbangan sifat-sifat manusia, muatan artefak dan lingkungannya. "Good design" menjadi tanggung jawab sekaligus pencapaian terakhir yang mutlak harus mampu dicapai oleh seorang desainer yang baik.

\section{DAFTAR PUSTAKA}

Abdullah, R., Hubner, R. (1991). Pictograms Icons\&Signs. New York: Watson-Guptill.

Follis, J., Hammer, D. (1968). Architectural Signing and Graphics. New York: Watson-Guptill. 
Frutiger, A. (1998). Signs and Symbols. New York: Watson-Guptill.

http// mutcd.fhwa.dot.gov/ kno-history htm

Joedawinata, A. November 2011. Materi Kuliah Estetika Terapan.

S.I No 55/1926 , Road Signs and Traffic Signals Regulations 1926 